\title{
Research on Energy Cooperation among Countries in China and along the Belt and Road Initiative
}

\author{
Yang Hou \\ International Business School \\ Yunnan University of Finance and Economics \\ Kunming, China \\ 1875744167@qq.com
}

\author{
Linlin Liang* \\ International Business School \\ Yunnan University of Finance and Economics \\ Kunming, China \\ 279653205@qq.com
}

\begin{abstract}
The concept of the "One Belt and One Road" is to promote cooperation and development among countries. Strengthening international energy cooperation is one of the important tasks of the "four revolutions and one cooperation" energy revolution strategy proposed by general secretary Jinping Xi. In the new era of "introducing" and "going out" in energy cooperation, we will fully grasp the new changes and new trends in international energy cooperation, and use the “One Belt and One Road" as a breakthrough point to develop more active international energy cooperation. It is very necessary to carry out more active international energy cooperation. It can be said that this topic is very practical.

This article is divided into four parts. Firstly, the research background and significance of this topic are introduced. Secondly, it deals with the status and fields of energy cooperation between China and countries along the Belt and Road Initiative.Thirdly, it proposes future cooperation modes and mechanisms. Finally, it summarizes the countermeasures and suggestions for cooperation among countries in the context of the Belt and Road Initiative.The last two chapters are the key research sections.
\end{abstract}

Keywords-"One Belt and One Road" energy cooperation; modes and mechanisms

\section{INTRODUCTION}

Energy is the most basic material foundation for China's national economic construction. At present, China is in a critical period of rapid economic development. It is also increasingly constrained by energy resources, and energy supply and demand are not balanced. As a result, a series of problems have arisen. Under this circumstance, energy cooperation with countries along the Belt and Road Initiative to ensure economic growth has become a good choice for solving problems.

The reason why the "One Belt and One Road" strategy has been participated by many countries is mainly due to the large number of countries along the "One Belt and One Road" initiative, with vast territory and abundant energy resources, including Russia, Kazakhstan, Iraq, Turkmenistan, Iran, Saudi Arabia, United Arab Emirates, Israel, etc [1]. As an important energy reserve country, the energy cooperation strategy between China and its neighboring countries is not only beneficial to China, but also promotes the development of the economic and energy industries in all resource countries. Therefore, energy cooperation is a feasible plan that is beneficial to all countries.

Through energy cooperation with countries along the Belt and Road Initiative the two sides can not only jointly study the current international energy situation, complement each other with strategic technological advantages, but also lay a foundation for possible future corporation. It is no exaggeration to say that carrying out "One Belt and One Road" energy cooperation can bring resources development and energy development to countries along the route, and it also brings vast markets to other countries' technologies and funds for energy development [2]. This will play a very important role in world economic growth and global common prosperity. In the case of the country itself, energy cooperation can expand the opening up of China's western region, increase oil and gas production in the western region, and increase the core competitiveness of energy companies. This is of great significance to China's overall energy cooperation strategy. Therefore, energy cooperation in countries along the Belt and Road Initiative is important. Cooperation can't be delayed.

\section{A. Overview of Foreign Studies}

Zhao Zhenyu, Feng Tiantian,Zuo Jian, George Zillante [3] believe that in the past few decades, the development of renewable energy in China has grown rapidly, which is a huge energy demand and the government's traditional fossil fuels in the energy mix the result of the function. Then it made a critical review of international cooperation in the renewable energy field in the new century, and concluded that the cooperation model varies from partner to partner. It also pointed out that China can benefit from international cooperation in renewable energy, such as access to capital and advanced technologies, development of human resources related to renewable energy, and strengthening of relevant policy frameworks.

Zhao Zhenyu, Zuo Jian ,Fan Leilei ,George Zillante [4] believe that China is facing a series of energy-related challenges such as shortage of electricity supply and environmental pollution. The government recognizes the important role of renewable energy in the power generation structure. Therefore, China has promulgated a series of supportive policies and regulations to promote the 
development of renewable energy, and finally found that the development model of renewable energy is closely related to the promulgation of related policies.

\section{B. Domestic Research Review}

Si Chuanyu [5] believes that the "One Belt and One Road" is a major initiative initiated by China in the profoundly changing international political and economic situation to open up space for cooperation and stimulate domestic economic growth. It is a major measure for China's opening up to the outside world. The "One Belt and One Road" involves many countries and the methods of cooperation are complex. Analysis of the dominant status of China's trade in the countries along the "One Belt and One Road" and the development of key cooperation areas, and put forward China's proposals for trade cooperation with countries along the "One Belt and One Road" initiative, thus promoting the signing of free trade agreements between China and countries along the route; Energy cooperation to ensure energy security; Strength cooperation in infrastructure construction.

Dong Xiucheng [6] believes that the international cooperation in oil and gas is an important part of the "One Belt and One Road" strategy. Analyzing the domestic and international environment and focusing on the opportunities and challenges faced by China's oil and gas international cooperation. It also proposes the introduction of supporting policies to guide various types of oil and gas companies participate in international oil and gas cooperation, insist on the coexistence of "oil and gas input" and "oil and gas output", build oil and gas trading centers and pricing centers, and continue to increase investment in oil and gas resources and mergers and acquisitions and other policy recommendations.

Lin Boqiang [7] believes that the realization of the "Belt and Road Initiative" is an important milestone in building a new order for international relations and realizing the great rejuvenation of the Chinese nation. Among them, energy cooperation is a promising area of the "One Belt and One Road" initiative.

\section{CuRrent Situation AND Field Of Energy CoOperation}

\section{A. The Current Situation of Energy Cooperation between China and Regions along the Belt and Road}

1) The state of energy cooperation between China and central Asia

Kazakhstan's crude oil resources in Central Asia are richer than other regions, while natural gas resources are more abundant in Turkmenistan and Uzbekistan. Therefore, China's current cooperation with Central Asia is mainly focused on crude oil and natural gas. For the preparations for the future supply of China-Kazakhstan oil pipeline and China-Central Asia natural gas pipeline, CNPC launched a new round of acquisitions and financial assistance. Onshore oilfields further consolidated the energy relations between China and other countries around the pipeline in 2003. For Chinese companies in Central Asia, that is, China Petroleum \& Chemical Corporation, Sinopec has always played an important role. In view of the fact that Kazakhstan' s crude oil resources are not only abundant but also have low costs, China will carry out long-term cooperation with crude oil .

2) The state of energy cooperation between China and the middle east

Energy cooperation between the Middle East region and China has been in a relatively stable state of development. Since President Xi Jinping visited Saudi Arabia, Egypt, and Iran, we have begun a new phase of bilateral energy cooperation. The current China-Egypt "New Suez Canal" project, the "New Capital Project", the China-Gulf Gulf State "China-Gulf Free Trade Area" negotiations and the ChinaIranian infrastructure projects are all diversified cooperation between China and the Middle East, Which performed. The Middle East is an important region in the world to study energy consumption and the future development of energy. Its share of global energy consumption has reached $8.8 \%$. The energy consumption of natural gas in the Middle East has reached a record high of $51.5 \%$. The Middle East still occupies an important position in energy export, accounting for more than $46 \%$ of global crude oil exports. Therefore, if China maintains long-term cooperation with the Middle East, it will be of great significance to the energy situation of both parties.

3) The state of energy cooperation between China, south Asia and southeast Asia

The energy cooperation between China and South Asia is mainly concentrated in this part of renewable energy. At the end of the 12th Five-Year Plan period, China's total oil imports from Central Asian countries accounted for $1.85 \%$ of its total oil imports, while the total natural gas imports accounted for $48 \%$. The import of oil and gas resources in Central Asian countries was effectively optimized. China's overseas energy supply structure. From the acquisition of Kazakhstan by China National Petroleum Corporation in 1997, energy cooperation between China and Central Asian countries has been going on for nearly 20 years. The national energy cooperation will continue and the energy cooperation between China and Southeast Asia will be more diversified, including official cooperation projects and non-official energy cooperation projects, including oil and natural gas trade, exploration and exploitation of oil and gas, and construction of renewable energy facilities, and maintenance and many other projects.

\section{B. The Area of Energy Cooperation under the "One Belt and One Road" Strategy}

There are many countries involved in the "One Belt One Road" Strategy. This includes different countries' different economic and energy development conditions. Therefore, the fields of energy development and cooperation in different countries are also quite different, but they mainly involve the following aspects: The upstream and downstream industries, the development and processing of coal mining products, the development and utilization of renewable energy and new energy. Energy cooperation in these three major areas has very clear prospects for China's future energy development . 


\section{ChINA'S ENERGy COOPERATION MODES AND MECHANISMS ALONG THE BELT AND ROAD INITIATIVE}

In order to continue the energy cooperation between China and the countries along the Belt and Road, the good cooperation model and cooperation mechanism between them is indispensable. If the current mode of cooperation is not suitable for the current development, this will require further countermeasures to solve this real-time problem in time.

\section{A. Energy Cooperation Mode}

\section{1) Intergovernmental cooperation mode}

The government plays an indispensable role in the implementation of the "One Belt and One Road" strategy. The governments of various countries use the current situation in the country to lay out the overall situation. In general, the modes of cooperation among governments mainly include the following: establishing a government-led multilateral energy conversation mechanism, signing road maps with countries along the route, building energy corridors, establishing energy financial cooperation institutions, etc.

\section{2) Cooperation mode between enterprises}

The mode of energy enterprise cooperation between China and the "Belt and Road" countries should not be rigidly adhered to the current mode of cooperation, but should gradually form a multinational or bilateral energy cooperation model led by Chinese companies, thereby deepening the implementation of various countries [8]. Cooperation between enterprises. Specifically speaking, Chinese enterprises should form a good cooperative and competitive relationship with foreign companies, establish energy cooperation alliances, participate in surveys and developments in related energy fields, and accelerate the signing of multilateral agreements between commercial banks and commercial organizations in various countries.

\section{B. Energy Cooperation Mechanism}

China should work out with the relevant countries the energy cooperation mechanism that can truly implement the "One Belt and One Road" strategy. Energy cooperation is not a simple energy trade. It needs to be strengthened in the following areas.

\section{1) Energy channel network cooperation and} transportation security mechanism

Energy transportation is of vital importance in the process of cooperation among countries. To achieve this, it is necessary to build an energy transportation network with oil and gas pipelines as the axis and rail and road transport as the auxiliary, so as to ensure the "One Belt and One Road" strategy [9]. Smooth progress. The main problem in this area is that the construction period of the transportation network is long and the effect is slow. Therefore, in order to ensure the timely supply of energy, a security maintenance mechanism should be established. The mechanism must be supported by the government. This can avoid unnecessary disputes that may arise when problems arise in the future. It also provides appropriate management institutions for the management of pipelines and can also play a role in reducing risks [10].

\section{2) Collective action mechanism}

As the name implies, the mechanism requires that all countries involved in cooperation take collective action. First of all, in terms of energy prices, both sides should unite the front to avoid unnecessary disputes. All countries negotiate and formulate energy prices that are satisfactory to everyone. In this process, different countries should not only consider costs, politics, and energy quality, but also have to negotiate on the basis of the energy conditions of each country [11]. At the same time, they must also consider emergencies and force factors. In short, the energy prices formulated must be acceptable and reasonable. Secondly, in the settlement of energy trade, we should shift from using the US dollar as the basis for direct trade with the renminbi. This can make the trade more smoothly, omitting the complicated procedures and enhancing the security of money. In this link, various financial institutions can be signed to sign service agreements. This is to ensure the smooth progress of energy trade.

\section{3) International energy dialogue mechanism}

This mechanism requires the establishment of an open regional cooperation platform to ensure the smoothness of dialogue channels at all levels and thus safeguard the interests of all countries. This can establish a working-level dialogue and cooperation mechanism and form parallel dialogues; establish a special dialogue and forum mechanism to promote cooperation in key areas of various countries; establish a comprehensive cooperation mechanism to promote the sustainability of energy cooperation and economic growth among countries, etc [12].

\section{4) Bank guarantee cooperation mechanism}

In this regard, the Chinese government should make use of its overall role and use government credit as a basis to promote the linkage innovation between government agencies and domestic commercial banks in energy cooperation so that cooperation between major companies can be deepened. At the same time, in order to improve the company's ability to resist risks, it is also possible to properly develop products that circumvent risks, guide enterprises to establish their own financial risk control and prevention mechanisms in respect of foreign investment, and at the same time, they must also push countries to "go global" and not rely solely on China [13]. It is necessary to jointly provide multilateral support for multilateral financial cooperation. Encourage countries to set up overseas financial branches to provide relevant services to relevant companies.

\section{COUNTERMEASURES AND SUGGESTIONS ON ENERGY COOPERATION BETWEEN CHINA AND "ONE BELT AND ONE ROAD"}

The contents of the previous chapters provide a brief overview of the current status of China's energy cooperation with countries along the Belt and Road, cooperation areas, and cooperation models. In response to these issues that may involve unresolved issues, relevant countermeasures and suggestions are proposed in the following aspects.

\section{A. Establish Infrastructure for Interconnection}

China should make full use of high technology such as information technology, high-speed rail and new energy to 
jointly maintain the safety of transportation routes such as oil and gas pipelines [14]. In establishing infrastructure for interconnection, China should speed up cooperation with the infrastructure of relevant countries, and focus on the construction of some key channels and important projects, so as to establish a convenient, efficient, and safe interoperable network construction.

\section{B. Using "AIA Investment Bank" and "Silk Road Fund" to Provide Financial Support}

The successful implementation of the "One Belt and One Road" strategy cannot be separated from the support of funds. As the AIIB, which mainly represents medium- and long-term bond financing, and the Silk Road Fund, which mainly represents medium and long-term equity financing, will undoubtedly play a very important role in this strategy [15]. China should make full use of the financial support of the AIIB and the Silk Road Fund, actively promote financial cooperation with countries along the Belt and Road Initiative, broaden financing channels, and gradually expand the scope and areas of cooperation between China's financial institutions and other countries so as to ensure "One Belt and One Road" strategy will not break before and after the implementation of the capital chain.

\section{Establish Bilateral or Multilateral Free Trade Zones}

Our country must gradually strengthen trade and financial exchanges with other countries, and it is best to sign bilateral or multilateral trade agreements with it. In this regard, the areas that are disadvantaged in our country are temporarily not open to the outside world. Then cooperation with various countries should begin with infrastructure, gradually expand the scope of cooperation, and at the same time reform the management system, make appropriate improvements to market access conditions, customs supervision, etc., speed up the negotiation process, and gradually establish free global trade. High standard trading network [16].

\section{Accelerating the "Going Out" Pace of Chinese Enterprises}

If an enterprise wants to become bigger and stronger, it cannot be confined to the country. It should gradually go out and look at the world. We should mobilize certain financial institutions to provide financial support for enterprises' external acquisitions and actively sign agreements with energy companies in resource countries. If major foreign projects are to be constructed, they should provide appropriate preferential interest on loans and interest rates. For overseas investment, a special investment insurance mechanism should be established. At the same time, the government should sign a safeguard agreement on foreign investment.

\section{E. Inclusive Development, Mutually Beneficial Trade, Long- Term Sustainability}

Under the "One Belt and One Road" background, China must adhere to the concept of cooperation that is "open, cooperative, mutually beneficial, and win-win." It must be open and inclusive to all countries, abandon their prejudices, accept differentiation among countries, and deepen cooperation. In the process of finding consensus to enhance the openness and transparency of communication ${ }^{[17]}$. At the same time, we should increase friendly exchanges and cultural exchanges among all countries, lay a good talent base and talent atmosphere for the "One Belt and One Road" strategy, and promote the continuity and inclusiveness of regional cooperation so as to create mutually beneficial trade.

\section{ACKNOWLEDGMENT}

The authors thank other members of the research group for helpful, valuable, and constructive comments and suggestions on earlier versions of this paper. The paper is supported by the National Natural Science Foundation of China (No.71663057).

\section{REFERENCES}

[1] Yang Lei. "International energy cooperation needs full empathy", China Petrochemical News.2018.

[2] Wang Yumin, "Energy cooperation is the new engine of "One Belt and One Road" economic development",China energy news.2017.

[3] Zhao Zhenyu,Zuo Jian,Feng Tiantian, George Zillante. "International cooperation on renewable energy development in China - A critica analysis", Renewable Energy.2010.

[4] Zhao Zhenyu,Zuo Jian,Fan Leilie, George Zillante, "Impacts of renewable energy regulations on the structure of power generation in China - A critical analysis", Renewable Energy.2010.

[5] Si Chuanyu, "Analysis and suggestions on the overall situation of China's trade cooperation with countries along the "One Belt and One Road"',Reform and strategy.2018.

[6] Dong Xiucheng, "The opportunities, challenges and countermeasures of China's oil and gas international cooperation under the "One Belt and One Road" strategy",Price theory and practice.2015.

[7] Lin Boqiang, "The "One Belt And One Road" initiative has a lot to do with energy cooperation”,China securities journal.2017.

[8] Zheng Jiahui. "In the background of "One Belt And One Road", the countermeasures of Chinese enterprises go out", China international finance.

[9] Werner Fasslabend, "The Silk Road:a political marketing concept for world dominance", European View.2015.

[10] Bangkok, "China:Energy cooperation to lead Silk Road economic belt", Asia News Monitor.2014.

[11] Zhang Lei, "Energy Cooperation under the Framework of "Silk Road Economic Belt"” , Economic issues.2015.

[12] Shi Ying,He Aiping, "Energy Cooperation and Environmental Risk Response in the Silk Road Economic Belt", Reform.2015.

[13] Cui Shoujun, "The Choice of China's Energy International Cooperation Model", Modern international relations.2010.

[14] Lin Boqiang, "The "One Belt and One Road" Initiative has promising potential for energy cooperation", China Securities Journal.2017.

[15] Bangkok, "China:Energy cooperation to lead Silk Road economic belt". Asia News Monitor.2014.

[16] Nylander Johan,"The perils of China's Silk Road revival", McClatchy Tribune Business News. 2014.

[17] Werner Fasslabend, “The Silk Road:a political marketing concept for world dominance” ,European View.2015. 